\title{
Ecological constraints on planktonic nitrogen fixation in saline estuaries. II. Grazing controls on cyanobacterial population dynamics
}

\author{
Francis Chan $^{1,2,4, *}$, Roxanne L. Marino ${ }^{1,3}{ }^{\text {, Robert W. Howarth }}{ }^{1,3}$, Michael L. Pace ${ }^{2}$ \\ ${ }^{1}$ Department of Ecology \& Evolutionary Biology, Corson Hall, Cornell University, Ithaca, New York 14853, USA \\ ${ }^{2}$ The Institute for Ecosystem Studies, Millbrook, New York 12545, USA \\ ${ }^{3}$ The Ecosystems Center, Marine Biological Lab, Woods Hole, Massachusetts 02543, USA \\ ${ }^{4}$ Present address: Department of Zoology, Cordley Hall, Oregon State University, Corvallis, Oregon 97331, USA
}

\begin{abstract}
Blooms of nitrogen $(\mathrm{N})$-fixing cyanobacteria are common in freshwater lakes of moderate to high productivity. In contrast, blooms of $\mathrm{N}$-fixing cyanobacteria are largely absent from the water columns of N-limited estuaries. In a companion study, we reported that the abundance and $\mathrm{N}$-fixation rates of planktonic filamentous heterocystous cyanobacteria are strongly suppressed by the presence of zooplankton consumers in saline estuarine mesocosms. Here, we show that bloom formation in these estuarine cyanobacterial N-fixers (Anabaena sp.) is strongly dependent on their ability to grow into sufficiently large filamentous colonies that are capable of developing heterocysts and thereby fixing $\mathrm{N}$. This basic physiological constraint on $\mathrm{N}$ fixation results in a sensitivity of $\mathrm{N}$-fixer bloom initiation to suppression by herbivorous zooplankton. In the presence of zooplankton consumers, small populations of heterocystous cyanobacteria exhibited reduced colonial filament size, decreased heterocyst frequencies, and suppressed growth rates. In short-term grazing assays, estuarine zooplankton (Acartia tonsa) directly consumed heterocystous cyanobacteria. This consumption occurred at high rates and resulted, at times, in marked reductions in colonial filament size. These results provide a mechanistic understanding of how trophic interactions can mediate the functional composition of phytoplankton communities and thereby constrain the biogeochemical response of estuaries to $\mathrm{N}$ limitation.
\end{abstract}

KEY WORDS: Nitrogen fixation · Heterocystous cyanobacteria - Estuaries · Zooplankton grazing

\section{INTRODUCTION}

The functional composition of phytoplankton communities represents a central link between species-level physiological adaptations and ecosystem-level properties such as export production, nutrient cycling, and food-web structure. For example, in freshwater and marine systems, the abundance of planktonic nitrogen (N)-fixing cyanobacteria is highly variable and can directly mediate and reinforce the transition between $\mathrm{N}$ and phosphorus limitation of primary production (Howarth et al. 1988a). For N-limited estuaries in particular, the near absence of planktonic biological fixation contrasts to the situation in oceans and productive lakes, where colonial $\mathrm{N}$-fixing cyanobacterial taxa are biogeo- chemically important components of phytoplankton communities (Howarth et al. 1988a). Resolving the factors that exclude or promote the invasion of biogeochemical functional groups such as $\mathrm{N}$-fixers into pelagic communities can thus provide important insights into cross-system patterns in nutrient supply and limitation.

With the exception of the Baltic Sea and a limited number of estuaries in Australia and South America (Lindahl \& Wallstrom 1985, Huber 1986, Perez et al. 1999), heterocystous cyanobacterial blooms are surprisingly absent from saline estuaries. Experiments indicate zooplankton grazers can be instrumental in inhibiting the invasion of heterocystous cyanobacteria into estuarine systems (Marino et al. 2002, 2006, this volume). Heterocystous cyanobacterial blooms 
reached densities in excess of 24000 cells ml ${ }^{-1}$ in estuarine mesocosms, but only when herbivores were excluded. In the presence of mesozooplankton grazers, heterocystous cyanobacteria either failed to appear entirely or were restricted to biogeochemically insignificant densities. In this and a companion paper (Marino et al. 2006), we present detailed results from seawater mesocosm experiments designed to elucidate the biogeochemical and ecological mechanisms that underlie this finding. Here, we explicitly consider the mechanisms by which consumers inhibit cyanobacterial blooms and the extent that grazer control of $\mathrm{N}$-fixer blooms may be decoupled from top-down control of estuarine production in general.

Although top-down control of $\mathrm{N}$-fixer blooms has been evident from freshwater systems (Elser et al. 2000), its effectiveness appears to be highly variable, and intensive zooplankton grazing is also known to promote cyanobacterial dominance (Hrbacek 1964, Sarnelle 1993). How estuarine consumers act to control $\mathrm{N}$-fixer blooms, and the extent to which consumer controls on $\mathrm{N}$-fixers may differ between freshwater and estuarine systems remain unclear. Recent models and experiments indicate that the structural and biochemical constraints of $\mathrm{N}$ fixation can accentuate the sensitivity of estuarine heterocystous cyanobacteria to consumer control relative to their counterparts in freshwater (Howarth et al. 1999, Marino 2001, Chan et al. 2004). Heterocystous cyanobacteria dominate in freshwater and in the limited number of estuaries where blooms of planktonic N-fixers occur (Schindler 1977, Lindahl \& Wallstrom 1985, Huber 1986). Heterocystous cyanobacteria grow as colonial filaments, comprised of fully photosynthetic cells and heterocysts. The latter are specialized diazotrophic cells that lack Photosystem II (Wolk et al. 1994, Adams \& Duggan 1999). The ability of heterocystous cyanobacteria to fix $\mathrm{N}$ and bloom is dependent on the production and maintenance of heterocyst activity by a sufficient number of adjacent photosynthetic cells (Howarth et al. 1999, Chan 2001). Conversely, reductions in the number of photosynthetic cells in a colony by grazers may lead to the suppression of heterocyst production and $\mathrm{N}$-fixation activities.

Across pelagic systems, herbivorous consumers represent an important, though variable, fate of autotrophic production (Cyr \& Pace 1993, Duarte \& Cebrian 1996). These losses of phytoplankton can be central in structuring the composition, biomass, and productivity of planktonic communities (Cloern 1982, Carpenter \& Kitchell 1988, Roman \& Gauzens 1997). Consumer-driven losses may mediate heterocystous cyanobacterial blooms, but this problem has not been considered especially with regard to how consumption may interact with bottom-up/population-size-structure constraints to N-fixer growth. In this paper, we used longer term mesocosm experiments and short-termed zooplankton:cyanobacteria grazing experiments to test the potential for grazers to suppress bloom formation of estuarine heterocystous cyanobacteria. Specifically, we tested: (1) the general ability of estuarine consumers to graze on heterocystous cyanobacteria, (2) the effects of grazing on population size structure in estuarine heterocystous cyanobacteria, and (3) the interactions between grazing and cyanobacterial life-history traits in constraining planktonic biological $\mathrm{N}$ fixation.

\section{MATERIALS AND METHODS}

Mesocosm experiments. We manipulated the abundance of herbivore consumers in estuarine mesocosms to test the sensitivity of planktonic heterocystous cyanobacteria to grazing control. Three separate experiments were carried out in the summers of 1994, 1996, and 1998, in a series of 30001 estuarine mesocosms located on the shore of Narragansett Bay, Rhode Island (details of the general experimental design can be found in Marino et al. 2006). Briefly, in 1994 (Expt 1), 10 mesocosms were used to test the effects of strongly N-limited conditions in stimulating heterocystous cyanobacterial blooms in the absence of mesozooplankton grazers. Five mesocosms received phosphorus $(+\mathrm{P})$, while 5 mesocosms received no experimental nutrient additions (Control). Mesozooplankton grazing pressure in all experiments was suppressed by addition of the zooplanktivorous fish Menidia berylina (15 individuals) to all tanks. In 1996 (Expt 2), 12 mesocosms were randomly assigned to 1 of 3 treatments: zooplankton grazing $(\mathrm{Gr})$, no zooplankton grazing (NGr), or benthic grazing (+Mussels). The +Mussels treatment received 7 Mytilus edulis individuals (35 to $45 \mathrm{~mm}$ in length). In 1998 (Expt 3), 16 mesocosms were randomly assigned as Gr or NGr treatments. Reductions in zooplankton grazing were again manipulated by the addition of $15 \mathrm{M}$. berylina to the NGr tanks. To ensure establishment of zooplankton populations, animals $(>100 \mu \mathrm{m})$ were collected from Narragansett Bay and held in 2 tanks of $3000 \mathrm{l}$ for 4 to $5 \mathrm{wk}$ prior to the establishment of the experimental mesocosms. The zooplankton culture/holding tanks received inorganic $\mathrm{N}, \mathrm{P}$, and Si nutrients in an atomic ratio of 20:1:20, at a rate of $3.2 \mathrm{mmol} \mathrm{N} \mathrm{m}^{-3} \mathrm{~d}^{-1}$. In 1996 and 1998, zooplankton from these 2 culture tanks were seeded to all experimental mesocosms at densities of 5000 and 7000 ind. $\mathrm{m}^{-3}$, respectively, within the first $2 \mathrm{wk}$ of the experiment to establish grazer populations.

Phytoplankton sampling. For both years, phytoplankton and chlorophyll samples were taken by inserting, capping, and withdrawing a $1 \mathrm{~m} \times 3.8 \mathrm{~cm}$ 
diameter PVC tube through the water column, while avoiding the mesocosm bottom, where aggregated algal matter had accumulated. Phytoplankton samples were preserved in $1 \%$ acid Lugol's solution (Wetzel \& Likens 1991). In 1996, phytoplankton samples were collected from each mesocosm tank twice weekly for the 10.5 wk duration of the experiment. Additional samples were collected daily from 28 August to the end of the experiment, coinciding with the first detection of heterocystous cyanobacterial cells in mesocosm tanks. Past experiments in these estuarine mesocosms indicated high temporal variation in heterocystous cyanobacteria (Marino 2001), and daily sampling allows more accurate depiction of population growth dynamics. Phytoplankton samples were collected from each mesocosm tank twice weekly for the $9 \mathrm{wk}$ duration of the 1998 experiment. In order to ascertain the short-term growth dynamics of $\mathrm{N}$-fixers, additional samples were collected daily from 28 July (upon the first appearance of $\mathrm{N}$-fixing cyanobacterial cells) to 7 August from each mesocosm in 1998. The effects of consumers on $\mathrm{N}$-fixing cyanobacterial abundance over the entire course of the experiments are presented in the companion paper (Marino et al. 2006). In order to elucidate the mechanisms of consumer suppression of cyanobacterial blooms, we focus in the present analysis on daily records of heterocystous cyanobacterial population structure, density, and growth.The abundances of heterocystous cyanobacterial (Anabaena sp.) vegetative cells, heterocysts, and filaments were enumerated after concentration by gravitational settlement or dilution with cell-free water in a $5 \mathrm{ml}$ counting cell at $100 \times$ and $400 \times$ on a Wild M-40 inverted microscope. Mean filament size, defined as mean number of cells within each colonial filament, and the heterocyst frequency, defined as the number of heterocysts per individual filament, were also determined. For each sample, 10 transects (representing $30.9 \%$ of the area of the counting cell) across the diameter of the counting chamber were counted. If $<50$ filaments were found in 10 transects, then all filaments in the counting chamber were enumerated. The growth rates $(r)$ of Anabaena sp. populations were calculated and normalized to $20^{\circ} \mathrm{C}$ using an assumed $Q_{10}$ value of 2 (Staal et al. 2003) as:

$$
r=\ln \left(N_{2} / N_{1}\right) / t_{1} / 2 \times \mathrm{e}^{0.0693(T-20)}
$$

where $N_{1}$ is the initial cell density at time $1, N_{2}$ is the cell density at Time $t, t$ is time in days where $1 / 2$ of maximum cell density was observed (Pielou 1969), and $T$ is the time-averaged temperature recorded in mesocosms. Chlorophyll samples were collected once per week in 1996 and 1998 on Whatman GF/F filters. The samples were kept frozen until analysis. Chlorophyll $a$ and phaeopigments were extracted in methanol
(Holm-Hansen \& Riemann 1978) and measured with a Turner Designs Model 10 fluorometer as in Marino (2001).

Mesozooplankton sampling. For Expt 1 (1994), mesozooplankton were sampled only at the start and end and only in duplicate tanks filled at the same time as the experimental tanks. A total of 125 to 2001 of water was sampled vertically over depth, using a low-speed, gasoline-driven pump, and then poured through a $63 \mu \mathrm{m}$ mesh plankton net. The concentrated samples were washed into a storage bottle with 95\% ethanol. In Expts 2 \& 3, mesozooplankton populations were sampled twice weekly to monitor the integrity of the zooplankton grazing treatments. In 1996, mesozooplankton samples were collected by pumping 651 through a $100 \mu \mathrm{m}$ mesh net. In 1998, mesozooplankton samples were collected by lowering and capping a $1 \mathrm{~m}$ PVC pipe through the water column. In this fashion $13 \mathrm{l}$ of water was collected and filtered through a $73 \mu \mathrm{m}$ mesh sieve. Comparison of the 2 methods found no differences in sampling efficiencies for calanoid adults, copepodites, or nauplii. Zooplankton samples were preserved in $75 \%$ ethanol, and were enumerated with stereomicroscopes for copepod adults, copepodites, and nauplii, as well as for cladocerans, polychaete larvae, and other metazoan larvae. Copepod adults and copepodites were further enumerated to the class level (i.e. calanoid, cyclopoid, and harpaticoid).

Mesozooplankton grazing experiments. Short-term grazing experiments were conducted in 1998 to test for direct consumption of heterocystous cyanobacteria by estuarine mesozooplankton. Four species of heterocystous cyanobacteria were employed: those present in the experimental mesocosms and the 3 cultured strains (University of Texas culture collection) Anabaena cylindrica (UTEX B269), Nostoc muscorum (UTEX LB1933), and Anabaena sp. (UTEX LB2497). No cyanobacteria of estuarine origin were available from culture collections, reflecting the paucity of planktonic heterocystous cyanobacterial blooms in saline estuaries. The UTEX cultures were used to test the generality of estuarine zooplankton consumption of heterocystous cyanobacteria. Mesozooplankton, consisting primarily (>95\% by density) of Acartia tonsa, were collected from Narragansett Bay and held in 2 outdoor zooplankton culture tanks of 30001 until used.

For each experiment, small samples of cyanobacteria were mixed with freshly collected $73 \mu \mathrm{m}$ mesh filtered Narragansett Bay seawater to create a mixed assemblage of natural estuarine phytoplankton and of a dilute population of cultured heterocystous cyanobacteria. Experiments with the phytoplankton assemblage were conducted in 9 to 16 (depending on experiment) polycarbonate flasks of $500 \mathrm{ml}$, to which adult and late stage (CIV and CV) copepodites (Acartia tonsa) were 
added at varying densities to create a gradient of grazing pressure. The densities ranged from 1 to 80 ind. $1^{-1}$, and were similar to the range of $A$. tonsa densities observed in Narragansett Bay during summer (Durbin \& Durbin 1981). In 1 experiment with Anabaena cylindrica, Acartia was anesthetized with carbonated water, individually pipetted into $120 \mathrm{ml}$ cups (containing seawater filtered through $73 \mu \mathrm{m}$ mesh Nitex netting) of 1 , 20,40 , or 80 ind. $\mathrm{l}^{-1}$, and then added to incubation flasks. In subsequent experiments, individuals of $A$. tonsa were dispensed from an aerated $1000 \mathrm{ml}$ seawater beaker using a wide-bore $10 \mathrm{ml}$ repeating pipette. The volume of water containing $A$. tonsa dispensed to each incubation flask was varied to establish a gradient of grazing pressure. The total volumes of all flasks were equalized by adding $73 \mu \mathrm{m}$ mesh filtered seawater. High survivorship (>95\%) was observed in the incubations with both zooplankton handling methods. Once filled, the flasks were mounted on a rotating plankton wheel (at $2 \mathrm{rpm}$ ) and incubated in a $20^{\circ} \mathrm{C}$ water bath under fluorescent lighting $\left(\sim 200 \mu \mathrm{E} \mathrm{m}^{-2} \mathrm{~s}^{-1}\right)$ for 4 to $6 \mathrm{~h}$. Initial and post-incubation phytoplankton samples were preserved in $1 \%$ acid Lugol's solution. Zooplankton samples were collected at the end of incubations and preserved in $75 \%$ ethanol. The abundances of heterocystous cyanobacterial cells, heterocysts, and filaments were enumerated as described above.

To test for relative feeding selectivity, changes in a natural assemblage of $>10 \mu \mathrm{m}$ length cylindrical pennate diatoms (i.e. similar in size to Anabaena sp.) were also recorded for 1 set of experiments involving estuarine Anabaena sp. from the experimental mesocosms. Selectivity coefficients (Vanderploeg 1981, Knisely \& Geller 1986) were calculated as the ratio of taxaspecific clearance rates (i.e. $F$ of Anabaena / F of pennate diatoms) according to the equation for clearance rates (Frost 1972):

$$
F_{\text {taxa }}=\left[\left(\ln C_{\mathrm{f}}-\ln C_{\mathrm{i}}\right)-\left(\ln C_{\mathrm{fg}}-\ln C_{\mathrm{i}}\right)\right] / t \times V / N
$$

where, $C_{\mathrm{i}}$ is the initial algal concentration in all flasks, $C_{\mathrm{f}}$ is the final algal concentration in control flasks, $C_{\mathrm{fg}}$ is the final algal concentration in grazing flasks, $t$ is the duration of the experiment, $V$ is the volume of the flask, and $N$ is the number of zooplankton per flask.

The taxa-specific ingestion rate per zooplankton, $I_{\text {taxa }}$ is equal to the taxa-specific filtration rate, $F_{\text {taxa }}$ times the mean concentration of algal cells, $C_{\mathrm{m}}$ and was calculated as:

$$
I_{\text {taxa }}=C_{\mathrm{m}} \times F_{\text {taxa }}
$$

Since the concentration of cells declines in the incubation flask over time, the mean algal cell concentration was estimated according to McClatchie \& Lewis (1986) such that:

$$
C_{\mathrm{m}}=\left(C_{\mathrm{i}} \times\{\exp [(k-g) \times t]-1\}\right) / t \times(k-g)
$$

where the instantaneous rate of phytoplankton growth, $k$, is equal to $\left(\ln C_{\mathrm{f}}-\ln C_{\mathrm{i}}\right) / t$, and the instantaneous rate of phytoplankton loss, $g$, is equal to $k-$ $\left(\ln C_{\mathrm{i}}-\ln C_{\mathrm{fg}}\right) / t$. Since the densities of consumers in these experiments were varied, we were able to calculate multiple estimates of $F$ and $I$ for each individual phytoplankton taxa. Estimates of $F$ and $I$ are dependent on the assumptions that $g$, the instantaneous mortality coefficient, is constant over the course of incubations or can be described as a time-averaged rate without bias (McClatchie \& Lewis 1986). However, behavioral changes in zooplankton grazers (e.g. functional responses to changes in food concentration) can result in changes to actual $g$ values during incubations (Rigler 1961, Chow-Fraser \& Sprules 1992). Since estimates of $g$ can vary depending on initial food concentrations and consumer densities (via potential for food depletion), estimates of $F$ based on any 1 ratio of food:consumer densities must be interpreted with caution (McClatchie \& Lewis 1986). To minimize possible biases associated with using a value of $F$ that is based on 1 food:consumer ratio, we pooled values of $F$ across consumer density treatments for our estimates of $F_{\text {taxa }}$ and $I_{\text {taxa }}$ for each specific phytoplankton taxa.

Statistical methods. For the mesocosm experiments, the responses of chlorophyll and heterocystous $\mathrm{N}$-fixer population size and structure (e.g. number of heterocysts per filament) were described as time-weighted means. All phytoplankton variables were log-transformed to equalize variance among treatments and to control for correlations between means and variance in the raw data. ANOVA tests of time-weighted means of log-transformed data were analyzed via Statview 5.0.1. Model II regressions were used to analyze the relationships between cyanobacterial population structures, size, and growth rate. Model I regressions were used in the analyses of short-term grazing results, as zooplankton density (the independent variable) was derived from counts of all individuals.

\section{RESULTS}

\section{Mesocosm experiments}

Mesozooplankton populations were highly sensitive to the presence or absence of zooplanktivorous Menidia berylina in all experiments. Mesozooplankton densities in the NGr and +Mussels treatments were largely held to $<1$ ind. $\mathrm{l}^{-1}$ for the entire experiment in 1996 (Fig. 1a,b) and for the first $6 \mathrm{wk}$ of the 1998 experiment (Fig. 2a). In the $1998 \mathrm{NGr}$ treatment, however, mesozooplankton populations increased in the final $4 \mathrm{wk}$ of 


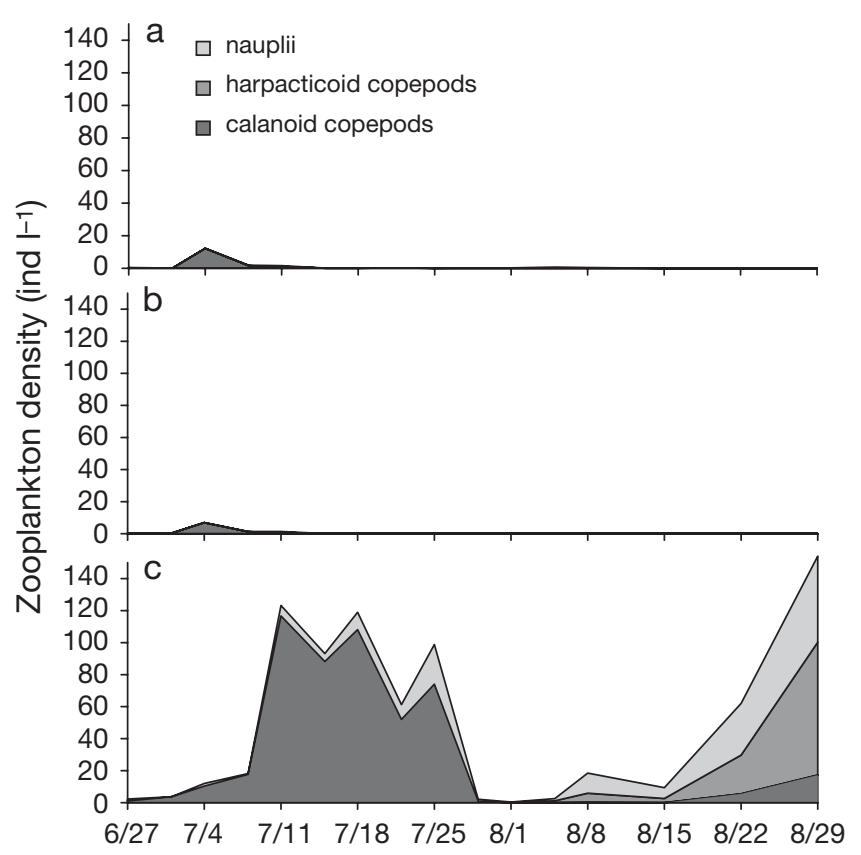

Fig. 1. Zooplankton density in the 1996 experiment: (a) no zooplankton grazing (NGr), (b) +Mussels, and (c) zooplankton grazing (Gr). Treatment means are plotted

the experiment (Fig. 2a). In the Gr treatments, adult and copepodite copepods averaged ca. 45 ind. $1^{-1}$ in both years (Figs. 1c \& 2b), similar to densities in Narragansett Bay during summer (Durbin \& Durbin 1981). The mesozooplankton community consisted primarily of Acartia tonsa adults, copepodites, nauplii, as well as harpaticoid copepods with minor contributions from polycheate and veliger larvae and other cyclopoid and calanoid copepods (Figs. 1c \& 2b). Mesozooplankton abundances in both years exhibited cycles of initial growth and decline, followed by a secondary period of increase. This resulted in marked reductions in grazing pressure for periods of up to $2 \mathrm{wk}$. The composition of the mesozooplankton community varied through time as well. In 1996, growth and decline periods in A. tonsa abundance were followed by a subsequent increase in a mixed assemblage of harpaticoid copepods and A. tonsa (Fig. 1c). In 1998, A. tonsa populations showed similar increase and decline periods, though with subsequent recovery (Fig. 2b). The recruitment and growth of individual $A$. tonsa cohorts (e.g. transition from N1 to N2 nauplii stages) were evident in the mesocosms. These cohort effects likely contributed to the observed population fluctuations.

In both years, the initial appearance and maximum peaks of heterocystous cyanobacterial blooms were captured by the daily samples. These blooms comprised pelagic populations of an Anabaena species, and benthic taxa such as Calothrix spp. were absent. The bloom abundances of heterocystous cyanobacteria

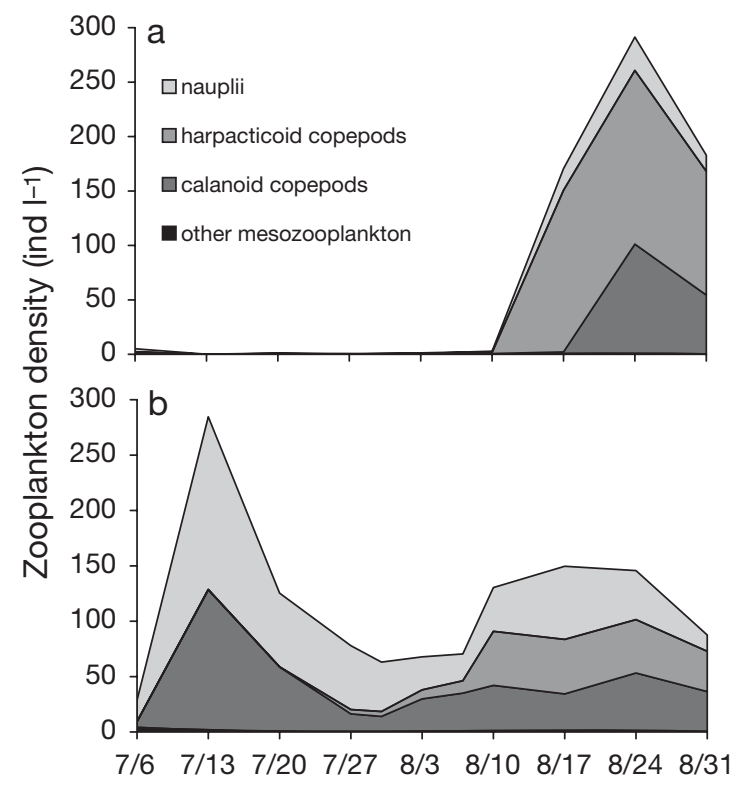

Fig. 2. Zooplankton density in the 1998 experiment: (a) NGr and (b) Gr mesocosms. Treatment means are plotted. 'Other mesozooplankton' include cladocerans and meroplankton and were found at densities too low to be depicted individually

were normalized to chlorophyll a concentrations, in order to test the relative sensitivity of cyanobacteria to suppression by consumer controls. In the 1996 experiment, the relative contribution of heterocystous cyanobacteria (Anabaena sp.) to the phytoplankton community was strongly suppressed by zooplankton grazers (Fig. 3a). Anabaena sp. densities in the Gr treatment were all below the limits of detection. The ratio of Anabaena cells to chlorophyll a was reduced 8-fold in the presence of Mytilus edulis relative to the $\mathrm{NGr}$ treatment. These differences were not significant and reflected, in part, high variances within the NGr treatment (i.e. reduction in grazing pressure alone did not consistently lead to blooms of heterocystous cyanobacteria). In 1998, mesozooplankton grazing again resulted in significant selective suppression of cyanobacterial abundance (Fig. 3a). Anabaena:chlorophyll ratios were reduced 25 -fold relative to the NGr treatment. The inhibition of Anabaena biomass was selective, as chlorophyll a concentrations were insensitive to or only moderately suppressed by the presence of consumers in the mesocosms (Fig. 3b).

Zooplankton grazing influenced the structure of Anabaena populations. Grazing restricted Anabaena to short filaments (mean colony size $=15.4$ cells) with fewer heterocysts (mean heterocyst per filament = 1.4 cells) (Fig. 4a,b). In contrast, Anabaena were longer (mean colony size $=46.3$ cells) and had more heterocyst-rich (mean heterocyst per filament $=3.3$ cells) filaments in the NGr treatment. In addition to reducing 

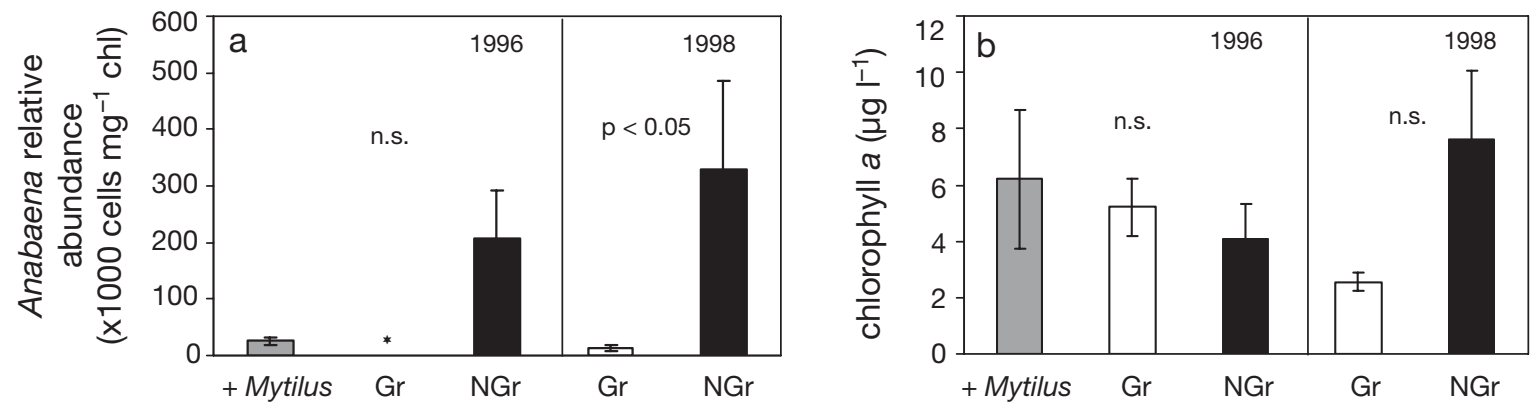

Fig. 3. (a) Reductions in the relative contribution of Anabaena cells to estuarine phytoplankton biomass due to the presence of Mytilus edulis and mesozooplankton consumers in 1996, and to mesozooplankton in 1998 (*: no Anabaena cells were observed in any Gr mesocosms in 1996). For 1996, contrast between +Mussels and NGr was not significant (1-way ANOVA on log-transformed data $\mathrm{p}>0.05$ ). In 1998, relative Anabaena abundance was significantly different between grazing treatments (1-way ANOVA on log-transformed data p < 0.05). (b) Response of chlorophyll to grazing in both 1996 and 1998 mesocosm experiments. Differences were not significant among treatments in either year. Untransformed time-averaged treatment means and standard errors of the mean (SE) are shown
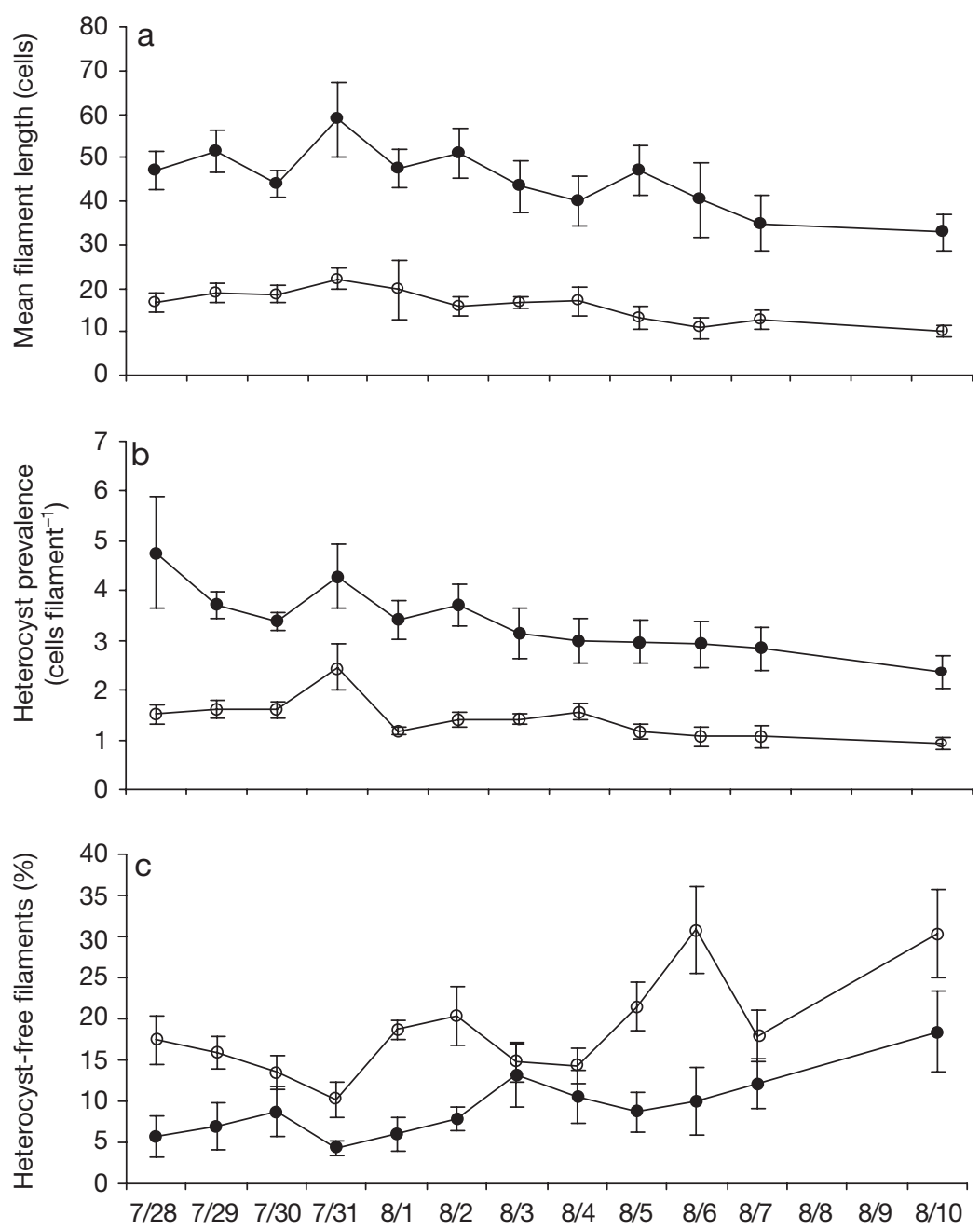

Fig. 4. Reductions in Anabaena (a) mean filament length, (b) heterocyst prevalence, and (c) population-level prevalence of N-fixation competent filaments in response to mesozooplankton grazing in the 1998 mesocosm experiment (O: Gr; $\bullet:$ NGr). Data are means ( $\pm 1 \mathrm{SE}$ ) the mean number of heterocysts per filament, zooplankton grazing also increased the proportion of filaments that lacked heterocysts and thus could not fix $\mathrm{N}$ (Fig. 4c).

The production of heterocysts and the N-fixation capacity in Anabaena is related to filament elongation and growth of photosynthetic, vegetative cells. The number of heterocyst(s) occurring on each filament increased linearly with increases in mean filament length (Fig. 5a). From the slope of this relationship, we estimate 16 vegetative cells supported the production and activities of 1 heterocyst. At the population level, the production of heterocysts is similarly tied to the growth of vegetative cells (Fig. 5b). Zooplankton-mediated changes in population size structure also translate directly into proportional changes in net rates of population growth. In temperaturenormalized net growth rates amongst mesocosm populations, $86 \%$ of the variance can be explained by variations in mean filament length (Fig. 5c). The consequences of filament-length reductions promoted the populationlevel reductions in cell density. Although the relationship between mean filament length and mean population size is variable $\left(\mathrm{R}^{2}=0.52\right)$, a doubling of filament length corresponds to an approximately 1 order of magnitude increase in Anabaena cell density (Fig. 5d). 

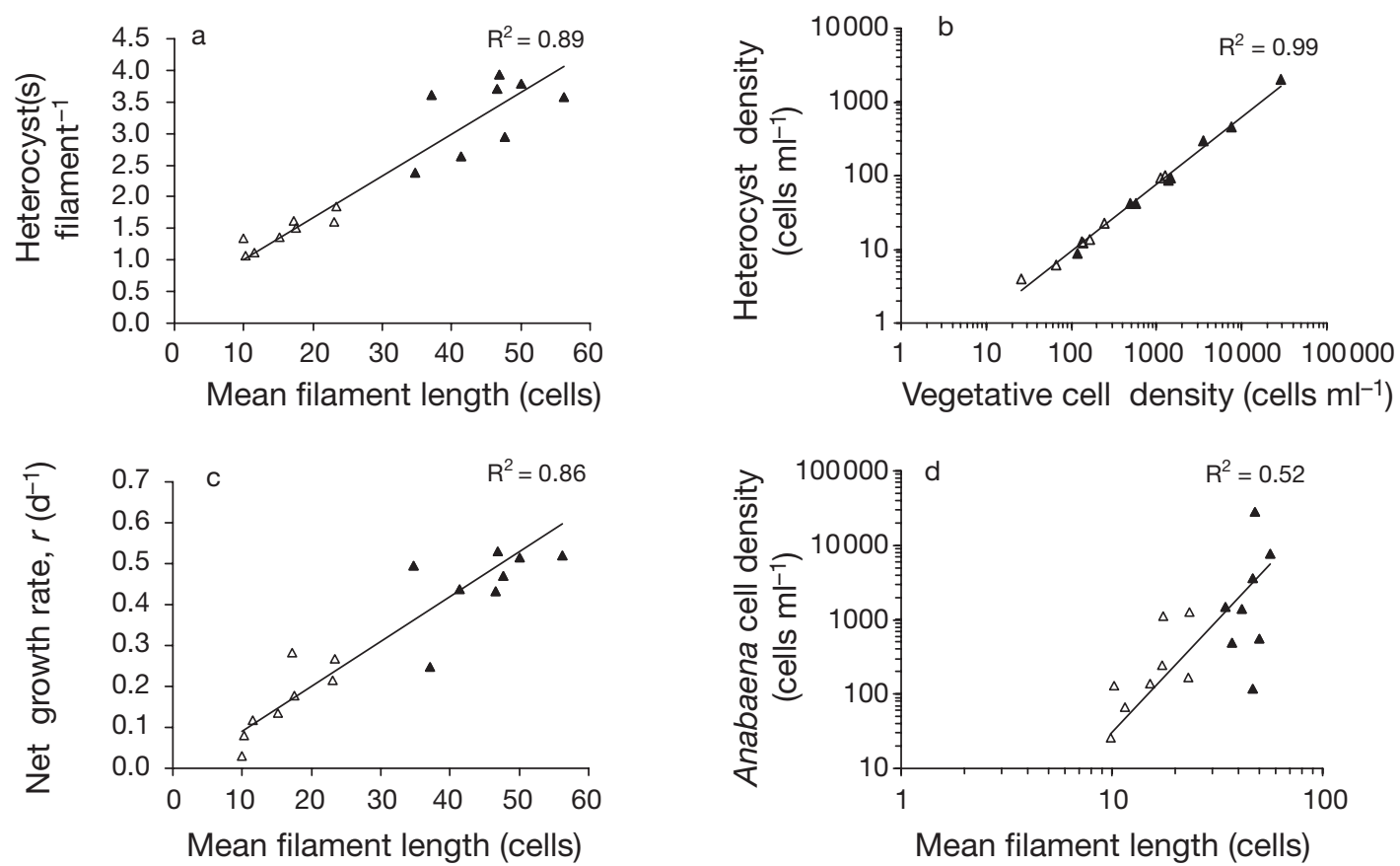

Fig. 5. Changes in (a) heterocyst prevalence, (c) net growth rates, and (d) mean population size in relation to mean filament length, and (b) dependence of heterocyst density upon vegetative cell density, in the 1998 experiment for Gr $(\Delta)$ and $\mathrm{NGr}(\boldsymbol{\Lambda})$ mesocosms. Net growth rates have been normalized to $20^{\circ} \mathrm{C}$

\section{Mesozooplankton grazing experiments}

Estuarine heterocystous cyanobacteria were readily consumed by mesozooplankton. Anabaena sp. cells incubated with Acartia tonsa declined by up to 4 -fold in density in $4 \mathrm{~h}$ relative to no-grazer controls (Fig. 6a). Relative to similarly sized diatoms, estuarine mesozooplankton showed no selectivity against Anabaena sp. from the experimental mesocosms (Fig. 6a, Table 1). Across the gradient of zooplankton densities, selectivity coefficient did not differ from 1 , as clearance rates $\left(\mathrm{ml}\right.$ ind $^{-1} \mathrm{~h}^{-1}$ ) for Anabaena sp. (mean $=0.82, \mathrm{SE}=$ 0.71 ) did not differ significantly from those for diatoms $($ mean $=1.14, \mathrm{SE}=0.38)($ paired $t$-test, $\mathrm{p}>0.05)$. These clearance rates are similar to those reported for A. tonsa adults ( $\sim 0.5$ to $4 \mathrm{ml}$ ind.$^{-1} \mathrm{~h}^{-1}$ ) fed highly edible taxa such as Rhodomonas baltica or Thallasiosira fluviatilis (Berggreen et al. 1988, Stottrup \& Jensen 1990).

At the concentration of cells offered, per capita ingestion rates averaged 114 cells $\mathrm{h}^{-1}$ for Anabaena sp. and 610 cells h$^{-1}$ for diatoms (Table 1). Acartia tonsa also readily grazed other species of heterocystous cyanobacteria. The densities of Anabaena cylindrica, Anabaena sp. UTEX 2497, and Nostoc musocrum all declined by up to 4 -fold in the presence of consumers relative to no-grazer controls (Fig. $6 \mathrm{~b}$ to d). Per capita ingestion rates ranged from 500 to 1000 cells $\mathrm{h}^{-1}$ for these cyanobacterial taxa (Table 1). These rates are similar to those observed for $A$. tonsa feeding on
N-enriched diatoms, Thalassiosira weissflogii (800 to 2000 cells animal ${ }^{-1} \mathrm{~h}^{-1}$ at initial algal density of 500 to 2500 cells ml-1 ${ }^{-1}$ (Cowles et al. 1988). Mesozooplankton grazing also had important impacts on the population structure of heterocystous cyanobacteria. Significant declines in mean filament lengths were observed for all 4 cyanobacterial taxa (Table 1). For example, estuarine Anabaena filaments averaged 17 cells in length in the no-grazer controls, but declined to 12 cells in length at high densities of Acartia (Fig. 6a).

\section{DISCUSSION}

Nitrogen-fixing cyanobacteria can reach biogeochemically important densities in saline (ca. 30 ppt) experimental systems (Marino et al. 2002, 2006). However, the potential for high densities of N-fixing cyanobacteria is strongly dependent on suppression of grazing pressure (Marino et al. 2002). Analyses of daily changes in population structure presented here indicate that grazer suppression of the $\mathrm{N}$-fixation potential and bloom formation reflect the sensitivity of heterocystous cyanobacterial growth to reductions in colonial filament size and heterocyst production. The strength of grazer control on primary production in coastal systems is variable, and thought to be generally weak relative to freshwater systems (Micheli 1999, Shurin et al. 2002). Nevertheless, in comparisons to overall phyto- 

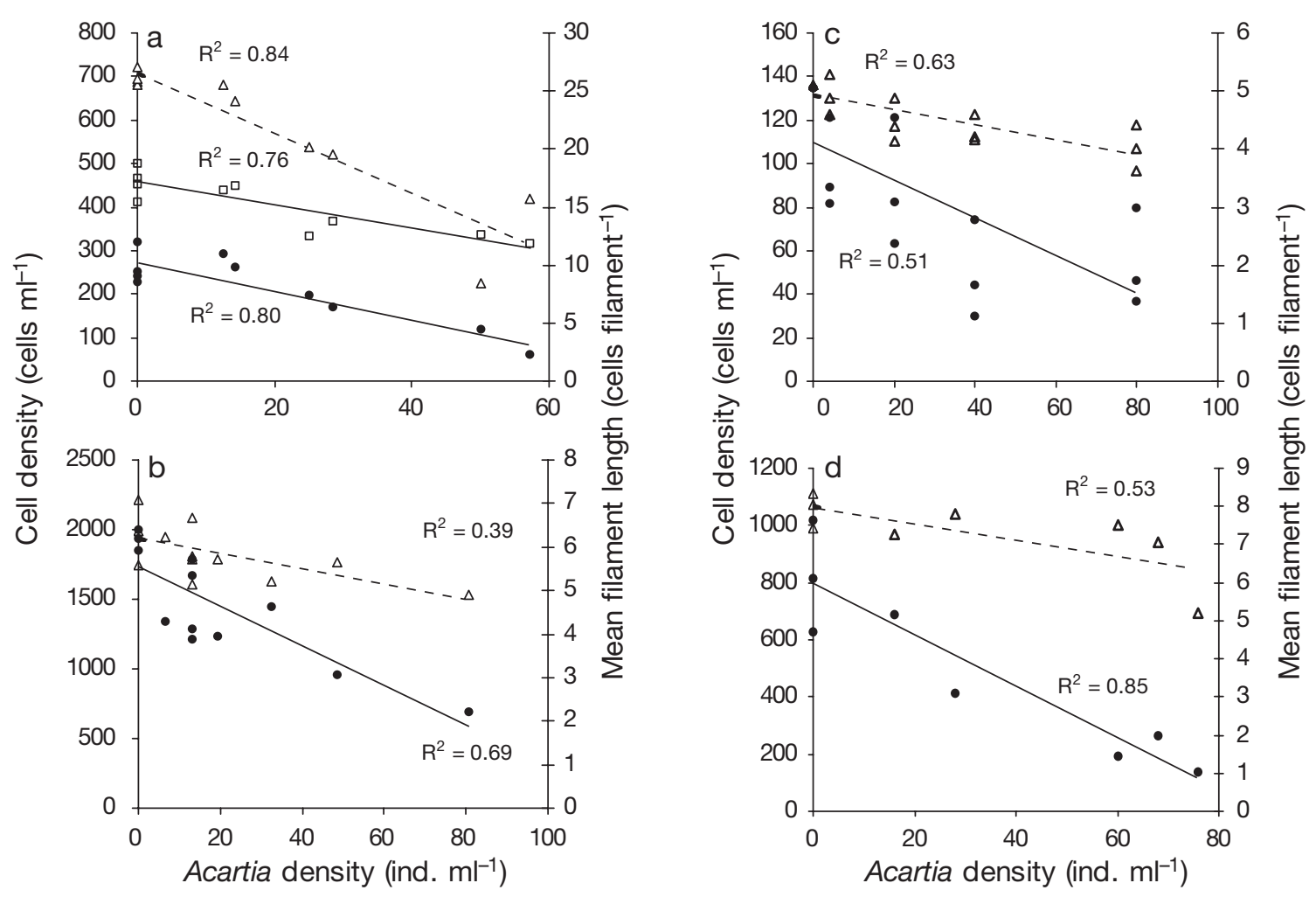

Fig. 6. Results of short-term studies on the consumption of heterocystous cyanobacteria by Acartia tonsa copepods. Results for (a) Anabaena sp. collected from estuarine mesocosms and Narragansett Bay diatoms, (b) Anabaena cylindrica (c) Anabaena sp. (UTEX 2497), and (d) Nostoc muscorum (•: cyanobacterial cell density; $\Delta$ : mean filament length; $\square$ : diatom assemblage)

plankton biomass, heterocystous cyanobacterial abundance was highly vulnerable to grazer control. This difference highlights the potential de-coupling of grazer control of planktonic N-fixer abundance from that of phytoplankton biomass. The distinction between trophic regulation of phytoplankton biomass and trophic regulation of phytoplankton community composition is important, because the presence of harmful or nuisance blooms depends on escaping various forms of control (including pre-bloom grazer control). In the experimental mesocosms, grazer control of phytoplankton biomass was weak, as evidenced by the lack of robust response of chlorophyll to grazing treatments. In contrast, the initiation of blooms in heterocystous $\mathrm{N}$-fixers and their potential for $\mathrm{N}$ inputs to the experimental systems were strongly curtailed by grazing pressure.

Selective consumer exclusion of heterocystous cyanobacteria from estuarine phytoplankton communities appears to arise from basic physiological constraints of $\mathrm{N}$ fixation. Extreme oxygen sensitivity in the nitrogenase enzyme complex and the concurrent energetic need for oxygenic photosynthesis pose a physiological challenge for autotrophic N-fixing cyanobacteria (Adams \& Duggan 1999). Cellular segregation of $\mathrm{N}$ fixation and photosynthesis allow heterocystous cyanobacteria to over- come these physiological constraints (Gallon 1992). However, our results suggest that cellular specialization of $\mathrm{N}$ fixation can also limit the ability of heterocystous cyanobacteria to fix nitrogen and bloom in the face of grazing mortality. In the experimental mesocosms, net growth rates of Anabaena populations were strongly tied to mean filament length and heterocyst frequency as mediated by zooplankton feeding (Fig. 5b,c). Shortterm grazing studies reported here and elsewhere have demonstrated the sensitivity of colony size in filamentous cyanobacteria (Schaffner et al. 1994, Turner et al. 1998) and estuarine diatoms (Deason 1980) to zooplankton grazing.

Heterocyst production was closely dependent upon the abundance of photosynthetic cells at the scale of individual filaments and at the population level (Fig. 5a,b). We found no evidence for high rates of heterocyst production when filaments were short or when the densities of photosynthetic cells were low. The ratio of vegetative to heterocystous cells was highly conserved (Fig. 5a,b), and suggests that sufficient filament growth must take place before $\mathrm{N}$ fixation can proceed, as hypothesized by Howarth et al. (1999). As short colonies with relatively low numbers of heterocysts, freshwater Anabaena populations suffered reduced gross rates of growth (Chan et al. 
Table 1. Regression (Model I) results for the effects of zooplankton consumption on population size and structure in heterocystic cyanobacteria; Acartia tonsa density (ind. $\mathrm{l}^{-1}$ ) is the independent variable in all cases. Intercept denotes the cell density or filament length at zero density of Acartia individuals, and slope represents the decline in cell density or filament length due to increases in Acartia density. Mean estimates of clearance rate $\left(F, \mathrm{ml}\right.$ animal $\left.{ }^{-1} \mathrm{~h}^{-1}\right)$ and ingestion rate $\left(I\right.$, cells animal $\left.{ }^{-1} \mathrm{~h}^{-1}\right)(\mathrm{from}$ individual +Zooplankton incubations) are also presented (n: the number of +Zooplankton incubation flasks). Grazing rates from Anabaena sp. (estuarine) and pennate diatoms were derived from the same experiment

\begin{tabular}{|c|c|c|c|c|c|c|c|}
\hline Dependent & $\mathrm{n}$ & $\begin{array}{c}\text { Initial } \\
\text { cell conc. } \\
\left(\text { cells ml }{ }^{-1}\right)\end{array}$ & $\begin{array}{c}F \\
(\mathrm{SE})\end{array}$ & $\begin{array}{c}I \\
(\mathrm{SE})\end{array}$ & $\begin{array}{c}\text { Intercept } \\
\text { ( } t \text {-value, } \\
\text { p-value) }\end{array}$ & $\begin{array}{c}\text { Slope } \\
\text { ( } t \text {-value, } \\
\text { p-value) }\end{array}$ & $\mathrm{R}^{2}$ \\
\hline \multicolumn{8}{|c|}{ Anabaena sp. (estuarine mesocosm) } \\
\hline Cell density & 6 & 280 & $\begin{array}{c}0.82 \\
(0.71)\end{array}$ & $\begin{array}{c}114.3 \\
(158.14)\end{array}$ & $\begin{array}{c}277.26 \\
(17.152,<0.0001)\end{array}$ & $\begin{array}{c}-3.336 \\
(-5.678,0.0005)\end{array}$ & 0.80 \\
\hline Mean filament length & & & & 17.155 & $\begin{array}{c}-0.100 \\
(31.285,<0.0001)\end{array}$ & $\begin{array}{c}0.76 \\
(-5.030,0.001)\end{array}$ & \\
\hline \multicolumn{8}{|l|}{ Pennate diatoms } \\
\hline Cell density & 6 & 712 & $\begin{array}{l}1.14 \\
(0.38)\end{array}$ & $\begin{array}{c}609.8 \\
(167.14)\end{array}$ & $\begin{array}{c}708.46 \\
(24.283,<0.0001)\end{array}$ & $\begin{array}{c}-6.899 \\
(-6.505,0.0002)\end{array}$ & 0.84 \\
\hline \multicolumn{8}{|l|}{ Nostoc muscorum } \\
\hline Cell density & 5 & 905 & $\begin{array}{c}1.99 \\
(0.46)\end{array}$ & $\begin{array}{c}1058.5 \\
(232.83)\end{array}$ & $\begin{array}{c}792.44 \\
(9.148,<0.001)\end{array}$ & $\begin{array}{c}-8.627 \\
(-4.299,0.0127)\end{array}$ & 0.82 \\
\hline Mean filament length & & & & 8.071 & $\begin{array}{c}-0.026 \\
(20.808,<0.0001)\end{array}$ & $\begin{array}{c}0.68 \\
(-2.923,0.0431)\end{array}$ & \\
\hline \multicolumn{8}{|c|}{ Anabaena sp. (UTEX 2497) } \\
\hline Cell density & 9 & 1322 & $\begin{array}{c}5.73 \\
(1.26)\end{array}$ & $\begin{array}{c}6308.7 \\
(1411.51)\end{array}$ & $\begin{array}{c}1739 \\
(19.088,<0.0001)\end{array}$ & $\begin{array}{c}-14.307 \\
(-4.755,0.0008)\end{array}$ & 0.83 \\
\hline Mean filament length & & & & 6.181 & $\begin{array}{c}-0.017 \\
(30.087,<0.0001)\end{array}$ & $\begin{array}{c}0.39 \\
(-2.520,0.0304)\end{array}$ & \\
\hline \multicolumn{8}{|l|}{ Anabaena cylindrica } \\
\hline Cell density & 12 & 129 & $\begin{array}{l}5.06 \\
(1.50)\end{array}$ & $\begin{array}{c}493.7 \\
(158.67)\end{array}$ & $\begin{array}{c}110.298 \\
(11.298,<0.0001)\end{array}$ & $\begin{array}{c}-0.877 \\
(-3.687,<0.0001)\end{array}$ & 0.51 \\
\hline Mean filament length & & & & 4.939 & $\begin{array}{c}-0.013 .63 \\
(44.398,<0.0001)\end{array}$ & $(-4.734,0.0004)$ & \\
\hline
\end{tabular}

2004). Prior to the formation of nitrogenase-competent heterocysts, the growth rate of heterocystous cyanobacterial cells in a N-limited system would be dependent on the uptake kinetics of $\mathrm{N}$ from the environment. As chains of relatively large spherical cells with low surface area to volume ratios, pre-bloom Nfixer populations may not be effective competitors for $\mathrm{N}$ or achieve high rates of population growth (see Foy 1980, Smith \& Kalff 1982). Moreover, heterocystous cyanobacteria are known to over-winter as akinetes (resting cells) in freshwater and estuarine sediments and to recruit to the water column as the akinetes germinate, increase in filament length, and produce heterocysts (Reynolds 1972, Huber 1984). Colony size dependent growth suggests that amongst estuarine phytoplankton, heterocystous cyanobacteria may be uniquely vulnerable to grazing. Unlike other phytoplankton with colony size independent growth, increases in grazing mortality lead to further reductions in the gross rate of growth for already slow-growing heterocystous cyanobacteria. By acting as a direct source of mortality and by suppressing the realized gross rate of growth, grazing can act to disproportionately exclude $\mathrm{N}$-fixers from estuarine phytoplankton communities.

The strength of grazer control in the initiation of Anabaena blooms is somewhat surprising. A large body of research has clearly pointed to the potential for freshwater and estuarine calanoids to select among food particles based on size, shape, nutritional content, and chemical defenses (e.g. Cowles et al. 1988, DeMott \& Moxter 1991). Research in freshwater systems has yielded variable results regarding the role of zooplankton consumption in the direct control of heterocystous cyanobacteria (Hrbacek 1964, Epp 1996). Zooplankton are known to reduce consumption rates on 
heterocystous cyanobacteria as a consequence of nutritional, chemical, and physical feeding deterrents (Webster \& Peters 1978, Holm et al. 1983, DeMott \& Moxter 1991). However, high rates of zooplankton consumption are also known for heterocystous cyanobacteria (Schaffner et al. 1994, Engstrom et al. 2000), even for taxa that are considered toxic (Koski et al. 2002, Kozlowsky-Suzuki et al. 2003). Results of the short-term grazing experiments indicate that estuarine zooplankton consume multiple species of heterocystous cyanobacteria while displaying no discrimination against Anabaena sp. collected from experimental mesocosms in mixed feeding trials with natural diatom assemblages from Narragansett Bay. Although extrapolation of short-term in vitro grazing rates to systemlevel rates must be done with caution, comparisons with grazing rates for non-cyanobacterial taxa reported elsewhere (Berggreen et al. 1988, Stottrup \& Jensen 1990) suggest that Acartia tonsa readily consumed a broad suite of heterocystous cyanobacteria at comparably high rates. Estuarine zooplankton are also known to feed selectively on individual phytoplankton cells that are of higher $\mathrm{N}$ content (Cowles et al. 1988). Consumption of heterocystous cyanobacterial cells may thus reflect trade-offs between higher $\mathrm{N}$ content in those cells and potential physical and chemical deterrents.

Factors such as N availability (MacKay \& Elser 1998) and turbulence (Moisander \& Paerl 2000, but see Howarth et al. 1993) can potentially influence colony length, heterocyst production, $\mathrm{N}$ fixation, and cyanobacterial success. Grazing by zooplankton consumers in particular can indirectly inhibit heterocystous cyanobacterial growth in systems in which stoichiometric differences in zooplankton and phytoplankton $\mathrm{N}: \mathrm{P}$ ratios and transient storage of $\mathrm{P}$ in zooplankton biomass favor the increased availability of DIN (MacKay \& Elser 1998, Elser et al. 2000). In the present studies, turbulence was held constant and DIN:DIP (dissolved inorganic nitrogen:dissolved inorganic phosphorous) ratios remained strongly below the Redfield ratio across all treatments in the mesocosm experiments (Marino et al. 2006). While turbulence, zooplankton-mediated increases in DIN:DIP, and direct zooplankton consumption and alteration of colony size structure are not mutually exclusive mechanisms, the lack of turbulence differences and the persistence of extremely low values of DIN:DIP across all treatments suggest that suppression of estuarine cyanobacterial blooms was a direct response to zooplankton consumption. The results of the short-term grazing studies further indicate that zooplankton directly grazed on heterocystous cyanobacteria, constrain filament elongation, and thus act to preempt the initiation of blooms (Howarth et al. 1999).

\section{Variability in grazer controls}

Although heterocystous cyanobacterial populations were highly vulnerable to grazer controls, consumer pressures can, nevertheless, vary widely among and within estuaries, and physical processes and nutrient availability are often dominant controls on primary production (Howarth et al. 1999). To what extent can trophic interactions act as a general mechanism in excluding planktonic $\mathrm{N}$-fixer blooms from most saline estuaries? Phytoplankton communities reflect both short-term (hours to days) and longer term (weeks to months) aspects of consumption, competition, recruitment, and abiotic variability (Sommer 1989). As a result, short-term fluctuations in grazing pressure may not translate into immediate responses in blooms. Considering that average rates of phytoplankton growth rate in situ are relatively constrained (i.e. on the order of 1 doubling d $\mathrm{d}^{-1}$ ) (Furnas 1990, Banse 1995), the response of rare, slow-growing taxa to temporary reductions in grazing pressure may take many weeks to realize. As an example, for a slow-growing phytoplankton $\left(0.21 \mathrm{~d}^{-1}\right), 6 \mathrm{wk}$ of mortality-free growth is needed to realize a 4 -order-of-magnitude increase in population size (i.e. bloom). Downward fluctuations in grazing pressure alone on weekly time scales may not be sufficient for promotion of $\mathrm{N}$-fixer blooms. Effective suppression of grazing pressure on seasonal time scales may be one requisite for the successful invasion of planktonic $\mathrm{N}$-fixers into estuary blooms.

\section{What factors are necessary to promote estuarine N-fixer blooms?}

Many factors regulate phytoplankton community structure in estuarine systems. The potential for any individual phytoplankton taxon to bloom will depend on the coincidence of high potential growth as determined by light availability, temperature, and nutrient supply, and marked reductions in rates of mortality (Kiørboe 1993). For estuarine N-fixers, the phenologic window for potential blooms is likely to be similarly constrained. Heterocystous cyanobacteria are known to bloom in a small number of estuaries, highlighting the consequences of relaxed constraints to N-fixer growth (Lukatelich \& McComb 1986, Perez et al. 1999). Indeed, the repeated development of Anabaena blooms in our grazing-suppressed mesocosms across years contrasts with their absence from the plankton communities of Narragansett Bay. This contrast further highlights the potential importance of trophic barriers to the establishment of estuarine $\mathrm{N}$-fixers. Moisander \& Paerl (2000) have also proposed that effective dispersal of heterocystous cyanobacteria from potential 
source populations in systems such as the Baltic might currently limit their successful invasion into N-limited estuaries of North America. Dispersal limitation and local ecological controls are not mutually exclusive processes, and may serve as interactive barriers to $\mathrm{N}$-fixer establishment.

\section{Contrasting controls on $\mathrm{N}$ fixation in freshwaters and estuaries}

Our results suggest that size structure dependent growth can subject heterocystous cyanobacteria to increased sensitivity to trophic controls relative to other estuarine phytoplankton taxa. Although size structure dependent cyanobacterial blooms (Chan et al. 2004) and grazing control of $\mathrm{N}$-fixer success (Elser et al. 2000) are also evident in freshwater systems, the general efficiency of grazer controls on N-fixer growth is, nevertheless, variable across freshwater systems (Carpenter 1989, Sarnelle 1993). The disparate effectiveness of freshwater and estuarine grazing suggests that additional factor(s) are likely to mediate the sensitivity of N-fixer blooms to grazing mortality.

Autotrophic $\mathrm{N}$-fixers have requirements for $\mathrm{Fe}$ and Mo that are up to 2 orders of magnitude greater than those of other phytoplankton taxa (Raven 1988). At the same time, the bioavailabilities of these elements can be quite low in oxic seawater (Howarth et al. 1988b, Martin et al. 1991). For estuarine N-fixers, reduced bioavailability of Mo, due to the inhibition of molybdate uptake by sulfate at seawater concentration, suppresses the growth rate of heterocystous cyanobacteria 2- to 3-fold relative to freshwater cyanobacteria (Marino et al. 2003). The consequence of this growthrate suppression appears great. The model by Howarth et al. (1999) explored population size structure dependent growth, trace-element limitation, and zooplankton consumption for freshwater and estuarine planktonic $\mathrm{N}$ fixation. The model results indicated that 2- to 3 -fold growth-rate reductions in seawater greatly increased the vulnerability of $\mathrm{N}$-fixers to the direct effects of zooplankton consumption (Howarth et al. 1999). The results of the present study confirm the mechanisms by which zooplankton consumers can act to disproportionately inhibit heterocystous cyanobacterial blooms in estuaries.

The functional composition of planktonic communities reflects, to varying degrees, the influences of resource availability, benthic and pelagic consumption, and physical losses due to sedimentation and advection (Reynolds 1987, Kiørboe 1998). In productive estuarine environments, where phytoplankton biomass turns over at rapid rates, the life-history traits of bloomforming taxa must reflect a successful trade-off be- tween high growth rate and resistance to grazing. Conversely, bloom formation or persistence is unlikely for taxa that attain only low growth rates and exhibit low resistance to consumers. The results of this study indicate that the physiological organization (colonial morphology and conserved ratio of vegetative:heterocystous cells) required for $\mathrm{N}$ fixation also makes heterocystous cyanobacteria vulnerable to grazer control. For estuarine heterocystous cyanobacteria, low intrinsic growth rates (reflecting potential factors such as Fe or Mo limitation) and high sensitivity to the effects of grazing may explain, in large part, their absence from estuarine waters. The disparate response of estuarine and freshwater systems may reflect, not only fundamental geochemical constraints to $\mathrm{N}$ fixation, but also their interactions with trophic controls.

Acknowledgements. This research was supported by a grant from the National Science Foundation (NSF) and by an endowment given to Cornell University by David R. Atkinson. Fellowship support to F.C. was provided by NSF-sponsored graduate training grants. We gratefully acknowledge the assistance of many staff and faculty members at the University of Rhode Island, and especially B. Buckley, S. Granger, S. Nixon, and M. Pilson, and D. Pelletier, T. Butler, S. Robbins, and M. Watson at Cornell University, as well as D. Fischer at the Institute of Ecosystem Studies. The USEPA laboratory in Narragansett, RI, provided support for purchasing some of the mesocosms and also provided fish for the experiment. We thank their staff, and particularly N. Jaworski.

\section{LITERATURE CITED}

Adams DG, Duggan PS (1999) Tansley Review No. 107: heterocyst and akinete differentiation in cyanobacteria. New Phytol 144:3-33

Banse K (1995) Zooplankton: pivotal role in the control of ocean production. ICES J Mar Sci 52:265-277

Berggreen U, Hansen B, Kiørboe T (1988) Food size spectra, ingestion and growth of the copepod Acartia tonsa during development: implications for determination of copepod production. Mar Biol 99:341-352

Carpenter SR (1989) Temporal variance in lake communities: blue-green algae and the trophic cascade. Landsc Ecol 3: 175-184

Carpenter SR, Kitchell JF (1988) Consumer control of lake productivity. BioScience 38:764-769

Chan F (2001) Ecological controls on estuarine planktonic nitrogen-fixation: the roles of grazing and cross-ecosystem patterns in phytoplankton mortality. PhD thesis, Cornell University, Ithaca, NY

Chan F, Pace ML, Howarth RW, Marino RM (2004) Bloom formation in heterocystic nitrogen-fixing cyanobacteria: the dependence on colony size and zooplankton grazing. Limnol Oceanogr 49:2171-2178

Chow-Fraser P, Sprules G (1992) Type-3 functional response in limnetic suspension-feeders as demonstrated by in situ grazing rates. Hydrobiologia 232:175-191

Cloern JE (1982) Does the benthos control phytoplankton biomass in south San Francisco Bay (USA)? Mar Ecol Prog Ser 9:191-202 
Cowles TJ, Olson RJ, Chisholm SW (1988) Food selection by copepods: discrimination on the basis of food quality. Mar Biol 100:41-49

Cyr H, Pace ML (1993) Magnitude and patterns of herbivory in aquatic and terrestrial ecosystems. Nature 361:148-150

Deason EE (1980) Potential effect of phytoplankton colony breakage on the calculation of zooplankton filtration rates. Mar Biol 57:279-286

Demott WR, Moxter F (1991) Foraging on cyanobacteria by copepods: responses to chemical defenses and resource abundance. Ecology 72:1820-1834

Duarte CM, Cebrian J (1996) The fate of marine autotrophic production. Limnol Oceanogr 41:1758-1766

Durbin AG, Durbin EG (1981) Standing stock and estimated production rates of phytoplankton and zooplankton in Narragansett Bay, Rhode Island, USA. Estuaries 4:24-41

Elser JJ, Sterner RW, Galford AE, Chrzanowski TH and 5 others (2000) Pelagic C:N:P stoichiometry in a eutrophied lake: response to a whole-lake food-web manipulation. Ecosystems 3:293-307

Engstrom J, Koski M, Viitasalo M, Reinikainen M, Repka S, Sivonen K (2000) Feeding interactions of the copepods Eurytemora affinis and Acartia bifilosa with the cyanobacteria Nodularia sp. J Plankton Res 22:1403-1409

Epp GT (1996) Grazing on filamentous cyanobacteria by Daphnia pulicaria. Limnol Oceanogr 41:560-567

Foy RH (1980) The influence of surface to volume ratio on the growth rates of planktonic blue-green algae. Br Phycol J 15:279-289

Frost BW (1972) Effects of size and concentration of food particles on the feeding behavior of the marine planktonic copepod Calanus pacificus. Limnol Oceanogr 17:805-815

Furnas MJ (1990) In situ growth rates of marine phytoplankton: approaches to measurement community and species growth rates. J Plankton Res 12:1117-1151

Gallon JR (1992) Tansley Review No. 44: reconciling the incompatible: $\mathrm{N}_{2}$ fixation and $\mathrm{O}_{2}$. New Phytol 122:571-609

Holm NPG, Ganf G, Shapiro J (1983) Feeding and assimilation rates of Daphnia pulex fed Aphanizomenon flosaquae. Limnol Oceanogr 28:677-687

Holm-Hansen O, Riemann B (1978) Chlorophyll a determination: improvements in methodology. Oikos 30:438-447

Howarth RW, Marino R, Lane J, Cole JJ (1988a) Nitrogen fixation in freshwater estuarine and marine ecosystems. 1. Rates and importance. Limnol Oceanogr 33:688-701

Howarth RW, Marino R, Cole JJ (1988b) Nitrogen fixation in freshwater estuarine and marine ecosystems. 2. Biogeochemical controls. Limnol Oceanogr 33:1859-1863

Howarth RW, Butler T, Lunde K, Swaney D, Chu CR (1993) Turbulence and planktonic nitrogen fixation: A mesocosm experiment. Limnol Oceanogr 38:1696-1711

Howarth RW, Chan F, Marino RM (1999) Do top-down and bottom-up controls interact to exclude nitrogen-fixing cyanobacteria from the plankton of estuaries? An exploration with a simulation model. Biogeochemistry 46: 203-231

Hrbacek J (1964) Contribution to the ecology of water-bloomforming blue-green algae: Aphanizomenon flos-aquae and Microcystis aeruginosa. Verh Int Verein Limnol 15: $837-846$

Huber AL (1984) Nodularia (Cyanobacteriaceae) akinetes in the sediments of the Peel-Harvey estuary Western Australia: potential inoculum source for Nodularia blooms. Appl Environ Microbiol 47:234-238

Huber AL (1986) Nitrogen fixation by Nodularia spumigena Mertens (Cyanobacteriaceae). 1. Field studies and the contribution of blooms to the nitrogen budget of the Peel-
Harvey estuary Western Australia. Hydrobiologia 131: 193-203

Kiørboe T (1993) Turbulence phytoplankton cell size and the structure of pelagic food webs. Adv Mar Biol 29:2-72

Kiørboe T (1998) Population regulation and role of mesozooplankton in shaping marine pelagic food webs. Hydrobiologia 363:13-27

Knisely K, Geller W (1986) Selective feeding of four zooplankton species on natural lake phytoplankton. Oecologia 69: 86-94

Koski M, Schmidt K, Engstrom-Ost J, Viitasalo M, Jonasdottir SH, Repka S, Sivonen K (2002) Calanoid copepods feed and produce eggs in the presence of toxic cyanobacteria, Nodularia spumigena. Limnol Oceanogr 47:878-885

Kozlowsky-Suzuki B, Karjalainen M, Lehtiniemi M, EngstromOst J, Koski M, Carlsson P (2003) Feeding reproduction and toxin accumulation by the copepods Acartia bifilosa and Eurytemora affinis in the presence of the toxic cyanobacterium Nodularia spumigena. Mar Ecol Prog Ser 249:237-249

Lindahl G, Wallstrom K (1985) Nitrogen fixation (acetylene reduction) in planktonic cyanobacteria in Oregrundsgrepen SW Bothnian Sea. Arch Hydrobiol 104:193-204

Lukatelich RJ, McComb AJ (1986) Nutrient levels and the development of diatom and blue green algal blooms in a shallow Australian estuary. J Plankton Res 8:597-618

MacKay NA, Elser JJ (1998) Differential nutrient recycling by Daphnia reduces nitrogen fixation by cyanobacteria. Limnol Oceanogr 43:347-354

Marino RM (2001) An experimental study of the role of phosphorus molybdenum and grazing as interacting controls on planktonic nitrogen fixation in estuaries. PhD thesis, Cornell University, Ithaca, NY

Marino RM, Chan F, Howarth RW, Pace M, Likens GE (2002) Ecological and biogeochemical interactions constrain planktonic nitrogen fixation in estuaries. Ecosystems 5: 719-725

Marino RM, Howarth RW, Chan F, Cole JJ, Likens GE (2003) Sulfate inhibition of molydenum-dependent nitrogen fixation by planktonic cyanobacteria under seawater conditions: a non-reversible effect. Hydrobiologia 500:277-293

Marino RM, Chan F, Howarth RW, Pace ML, Likens GE (2006) Ecological constraints on planktonic nitrogen fixation in saline estuaries. I. Nutrient and trophic controls. Mar Ecol Prog Ser 309:25-39 (this volume)

Martin JH, Gordon M, Fitzwater SE (1991) The case for iron. Limnol Oceanogr 36:1793-1802

McClatchie S, Lewis MR (1986) Limitations of grazing rate equations: the case for time-series measurements. Mar Biol 92:135-140

Micheli F (1999) Eutrophication, fisheries and consumerresource dynamics in marine pelagic ecosystems. Science 285:1396-1398

Moisander PH, Paerl HW (2000) Growth primary productivity and nitrogen fixation potential of Nodularia spp. (Cyanophyceae) in water from a subtropical estuary in the United States. J Phycol 36:645-658

Perez MC, Bonilla L, de Leon S, Smarda J, Komarek J (1999) A bloom of Nodularia baltica-spumigena group (Cyanobacteria) in a shallow coastal lagoon of Uruguay South America. Arch Hydrobiol Suppl Algol Stud 128:91-101

Pielou EC (1969) An introduction to mathematical ecology. Wiley-Interscience, New York

Raven JA (1988) The iron and molybdenum use efficiencies of plant growth with different energy carbon and nitrogen sources. New Phytol 109:279-288

Reynolds CS (1972) Growth gas vacuolation and buoyancy in a natural population of blue-green algae. Freshw Biol 2:87-106 
Reynolds CS (1987) Cyanobacterial water-blooms. Adv Bot Res 13:68-145

Rigler FH (1961) The relationship between concentration of food and feeding rate of Daphnia magna. Can J Zool 39: 857-868

Roman MR, Gauzens AL (1997) Copepod grazing in the equatorial Pacific. Limnol Oceanogr 42:623-634

Sarnelle O (1993) Herbivore effects on phytoplankton succession in a eutrophic lake. Ecol Monogr 63:129-149

Schaffner WR, Hairston NG Jr, Howarth RW (1994) Feeding rates and filament clipping by crustacean zooplankton consuming cyanobacteria. Verh Int Verein Limnol 25: 2375-2381

Schindler DW (1977) Evolution of phosphorus limitation in lakes: natural mechanisms compensate for deficiencies of nitrogen and carbon in eutrophied lakes. Science 195: $260-262$

Shurin JB, Borer ET, Seabloom EW, Anderson K, Blanchette CA, Broitman B, Cooper SD, Halpern BS (2002) A crossecosystem comparison of the strength of trophic cascades. Ecol Lett 5:785-791

Smith REH, Kalff J (1982) Size-dependent phosphorus uptake kinetics and cell quota in phytoplankton. J Phycol 18: $275-284$

Sommer U (1989) Nutrient status and nutrient competition of phytoplankton in a shallow hypertrophic lake. Limnol Oceanogr 34:1162-1173

Staal M, Meysman F, Stal LJ (2003) Temperature excludes $\mathrm{N}_{2}$-fixing heterocystous cyanobacteria in the tropical ocean. Nature 425:504-507

Stottrup JG, Jensen J (1990) Influence of algal diet on feeding and egg-production of the calanoid copepod Acartia tonsa Dana. J Exp Mar Biol Ecol 141:87-105

Turner JTR, Hopcroft R, Lincoln JA, Huestis CS, Tester PA, Roft JC (1998) Zooplankton feeding ecology: grazing by marine copepods and cladocerans upon phytoplankton and cyanobacteria from Kingston Harbour Jamaica. PSZN I: Mar Ecol 19:195-208

Vanderploeg HA (1981) Seasonal particle-size selection by Diaptomus sicilis in offshore Lake Michigan. Can J Fish Aquat Sci 38:504-517

Webster KE, Peters RH (1978) Some size-dependent inhibition of larger cladocerans filterers in filamentous suspensions. Limnol Oceanogr 23:1238-1245

Wetzel RG, Likens GE (1991) Limnological analyses, 2nd edn. Springer-Verlag, New York

Wolk CP, Ernst A, Elhai J (1994) Heterocyst metabolism and development. In: Bryant DE (ed) The molecular biology of cyanobacteria. Kluwer Academic Publishers, Dordrecht, p 769-823

Submitted: September 1, 2004; Accepted: August 21, 2005 Proofs received from author(s): February 3, 2006
Editorial responsibility: Otto Kinne (Editor-in-Chief), Oldendorf/Luhe, Germany 